\title{
Teachers Implementation of Effective Classroom Management from Vocational Education Students' Perspectives
}

\author{
Mufadi Al- Momani ${ }^{*}$, Zuhair Allouh ${ }^{1} \&$ Mohmad Al-homran ${ }^{1}$ \\ ${ }^{1}$ Dept. of Applied Science, Al-Balq'a' Applied University, PO Box 50, Al- Huson, Irbid, \\ Jordan \\ *Corresponding author: Mufadi Al- Momani, Dept. of Applied Science, Al-Balq'a' Applied \\ University, PO Box 50, Al- Huson, Irbid, Jordan \\ Tel:+962777720350Ｅ- mail: mufadi20@yahoo.com \\ Received: May 7, 2012 Accepted: August 18, 2012 Published: September 20, 2012 \\ doi:10.5296/ije.v4i3.1802 URL: http://dx.doi.org/10.5296/ije.v4i3.1802
}

\begin{abstract}
The researchers examined the extent of implementation of the effective classroom management components by teaching stuff of vocational education at Al- Huson University College, Al-Balq'a' Applied University, Jordan from the perspective of vocational education students' (bachelor degree). To achieve the objectives of the study the researchers used a questionnaire which has the necessary components, it was prepared by the researchers in the light of studies and scientific literature related to the subjects of the study.

The purpose of this study was to identify the opinions of vocational education students' at AlHuson University College, Al-Balq'a' Applied University. It also showed how effective classroom management components are applied by the teaching staff of Al Huson University College, and to determine the influence of some other factors like (gender , academic year level, specialization, practical subject), on this evaluation.

The sample of the study consisted of (152) students from all vocational education students at Al Huson University College that are registered in the first semester of the academic year $2010 / 2011$.

The questionnaire consists of ( 34 ) items used to collect the data which were analyzed by using SPSS program so as to compute the means, standard deviation and t- test.

The study showed that the scale items got positive evaluation from all the students. And there are no statistically significant differences between students due to gender or academic year.
\end{abstract}

Keywords: Classroom management, Classroom learning management, Learning management 


\section{Introduction}

University education is considered a key role in the progress and development of societies and it aims to prepare scientific, technical, managerial and administrative cadres in modern societies which is the top of the educational system, (Saber, 1982).

Al-Balq'a Applied University, Jordan has been established as a distinguished educational institution specialized in the field of applied science to meet Jordan needs of specialists, technicians, and to reduce unemployment among Jordanians. The University also supports research making in the different stages of university education and considers practical experience as an essential part of the study plan for all university students both in associate and university degrees. (Al-Balq'a Applied University / Strategic Plan).

Al-Balq'a Applied University offered the Bachelor degree in vocational education in Al Huson University College which seeks to develop essential teaching skills in students (prospective pre-vocational teachers). The program focuses on classroom management to allow student to acquire the necessary qualifying qualities for their future jobs as teaching pre-vocational education courses for $1^{\text {st }}$ to $10^{\text {th }}$ school grades in Jordan school.

These vocational programs have to go through a continuous process of evaluation and development in a way that makes them always be fresh and up-to-date. The process also makes the programs follow the technological and scientific breakthroughs in various fields. This requires procedures of continuous evaluation of the effectiveness of teaching in all the departments of the university, and to make sure that the goals drawn by the university which aim at providing graduates with the means of theoretical and practical knowledge to achieve the requirements of the contemporary labor market are accomplished. The research process of evaluating the effectiveness of teaching has gone through few phases that initially focused on classroom management. The first phase include identifying the personal qualities of a successful teacher, examining teaching methods and techniques, giving attention of the classroom environment and what happens inside classrooms of successful teachers, identifying competencies, skills, abilities and teaching methods that characterize him.( Medlay, 1979 ; Feldman, 1976).

Classroom management is one of the essential competences for efficient teacher among a set of competences that are determined according to an agreed upon behavior and an acceptable standard,(Yosef and Naefh Qutami, 2002).

The effectiveness of teaching has been discussed from different perspectives. Researchers gave effective teaching multiple definitions; each addressed a particular aspect and most of them agreed on the main points. This agreement proposes the existence of several common factors among them as Ibrami pointed that the effectiveness of teaching can be defined in three ways, each focuses on a particular aspect.

The first definition deals with it from the perspective of learning outcomes, as it focuses on positive change in the learner's behavior. The second focuses of the processes and activities carried out by the teacher while the third deals with the effectiveness of teaching of both aspects to determine what a successful teacher does to cause a positive change among 
students (Abrami, 1997).

(Emmer, Everston, Sanford and Clement, 1987) mentions number of attitudes in classroom management, learning management and classroom system. These attitudes, which focused on the importance of considering the student, and the importance of increasing his achievement. Therefore efficient teacher become the teacher who owns the effectiveness of classroom learning management and classroom organization that appears on the performance of students.

\section{Methodology}

\subsection{Questions of the Study}

The present study aims at identifying the opinions of vocational training students about how effective classroom management components are applied by the teaching staff at $\mathrm{Al}$ Huson University College as well as finding correlation between variables such as gender and year levels of students through answering the following questions:

1) To what degree is effective classroom management components are applied by teaching staff of the vocational education department from the perspective of students?

2) Does the degree of applying effective classroom management components vary according to their gender?

3) Does the degree of applying effective classroom management components vary according to the students' academic year level?

\subsection{Limitations of the Study}

The study is related to assumptions and limitations such as some procedures regarding the size of the sample and manner of choosing it, credibility and accuracy of the study tool, assuming the objectivity of students through the tool of the study. All what is mentioned are factors that affect the authenticity of the study results and provides credibility for the generalizations that affect results.

\subsection{Importance of the Study}

The Importance of this study lies in the following:

- Offering awareness of standard of the teaching staff at Al Huson University College regarding the application of different effective class management components from the perspective of vocational education students.

- Investigating some factors that might affect the assessment of students on their teachers' classroom management such as gender and the academic year level of subjects of the study.

\subsection{Statement of the Problem}

Classroom management is the cornerstone of teaching in all education levels, effective 
classroom management is an equivalent to "teaching administration,( Yosef and Naefh Qutami, 2002). It could lead to effective teaching, and is considered an art and a science, as an art it depends on a range of aspects related to the teacher character and his style in dealing with students in and outside the classroom, planning for the lesson and taken into account the behavior of students in a particular classroom climate and meeting the needs of the students to organize and arrange classroom environment and to keep it convenient for students so that he achieves the desired educational objectives. Classroom management is considered a science by itself through its regulations and procedures.

For all what has been mentioned above, identifying the degree in which effective classroom management components is applied by the teaching staff of vocational education at Al Huson University college is of a vital importance thus it is important as it can help in developing the teaching-learning process and to achieve effective learning.

\subsection{Operational Definitions}

Classroom Management: All behaviors and the components of classroom management that lead to creating a convenient classroom environment, Kauchak and Eggen, 1992.

Management of classroom learning: The conceptual equivalent of classroom management to the processes of mentoring and directing the efforts of a teacher and his students in classroom and also related behavior patterns which are directed to provide the necessary atmosphere to achieve the planned educational goals. That refers to the administration of different education-related issues and circumstances that make the process of learning in a classroom possible in the light of the desired educational goals, (Wolfgang, 1995).

The process involves precisely defining the roles of both the teacher and student and what the teacher does of organizing educational experiences, materials and tools that contribute in facilitating the process of learning. Moreover, the process include developing the process of learning to reach the maximum learner's potentials and give him a chance to self-realization. It allows the learners to integrate into a situation in which he develops an interactive, dynamic and energetic personality that dominates resources of the environment yet independent of the decisions,(Wang, M., Kargel,G., and Walberg, 1994).

Learning management: The concept of learning management of the educational situation which conceptually equivalent to the concept of classroom management Indicates that it's the . processes to guide and lead the efforts of the teacher and his students in the classroom and its behavioral patterns associated it, towards the provision of the climate necessary to attain the planned educational goals. Wolfgang, C., (1995).

\subsection{Study population}

The study population consisted of all students of Al- Huson University College - Balqa Applied University, Jordan. Both males and females enrolled in the study in vocational education program in the bachelor degree program in the first semester of the academic year 
2010/2011.They were 637 students according to the official college statistics.

\subsection{The study sample}

The study sample consists of 152 students who were randomly selected from the study population.

Table (1) shows the distribution of the sample according to their gender.

Table 1: The numbers of the study sample according to gender

\begin{tabular}{ll}
\hline Number of students & Gender \\
\hline 58 & Males \\
94 & Females \\
152 & Total \\
\hline
\end{tabular}

\subsection{Instruments of the Study}

All the necessary data collected for the sake of the study are an outcome of the assessment tool (Questionnaire). It was prepared by the researchers on the light of the previously mentioned studies and scientific literature related to the subject of the study (Yosef and Naefh Qutami, 2002). The study was given to a number of teacher referees in Al Huson University College who had a $\mathrm{PhD}$ degree and Ms.C degree in education and experienced in this field. They were asked to give some notes concerning the suitability of items to the study objectives and amending, omitting or adding any if necessary. The credibility of the study tool has been assured through the processes it went through. Likert scale questionnaire that uses five degrees ranging from $(1)=$ strongly disagree to $(5)=$ strongly agree was used and students were asked to put an " $x$ " sign in the place that represented the suitable response.

The study conducted by (Mamdoh Soliman and Abaas Adiby) was considered. The study aims at reaching a means of choosing a suitable classroom management tool. They stated the following four essential classroom management aspects to achieve a convenient educational environment, (Youssef Katamy 2002).

The final form of the study consisted of 34 items distributed over four domains. The first includes aspects related to the behavior of students and it had six items. The second included aspects concerning classroom atmosphere and the need of students and it had 12 items. The third included aspects related to planning for a lesson and educational tasks and it had 12 items. The fourth included aspects related organizing and preparing classroom environment and it had 5 items. Transaction consistency of the scale as a whole reached 0.91 .

\subsection{Procedures of the study}

The study tool was applied during the last week of the first semester of academic year 2010/2011. The questionnaire was distributed to the subjects of the present study by the researchers during the regular working hours as they meet with the subjects of the study to 
clarify the objectives of the study to them and to explain the proper way to answer the paragraphs of the questionnaire.

\section{Results and Statistical Analysis}

The questionnaire included four main domains of assessing the degree in which the teaching staff at Al Huson University College apply effective classroom management components. Students were asked to give their opinions about (34) items following Likert scale. Table (2) shows the mean and standard deviations for the responses of students to each item of the questionnaire.

Table 2: Mean and Standard Deviations for the responses of students to each item of the questionnaire

\begin{tabular}{|c|c|c|c|}
\hline $\begin{array}{l}\text { Item } \\
\text { no. }\end{array}$ & Item & $\begin{array}{l}\text { Standard } \\
\text { deviations }\end{array}$ & Mean \\
\hline 1 & Shows desirable attitude through praising & .79316 & 3.7437 \\
\hline 2 & Treats students strictly and fairly & 1.14297 & 3.2105 \\
\hline 3 & Deals with misbehaving students appropriately & 1.09434 & 3.0329 \\
\hline 4 & Carefully observes uneven behavior & 1.24170 & 3.3553 \\
\hline 5 & Avoids treating students harshly & 1.11511 & 3.4605 \\
\hline 6 & Does not ignore uneven behavior & 1.07230 & 3.6250 \\
\hline 7 & Considers the level of attention of students & 1.15237 & 3.5987 \\
\hline 8 & Providers friendly atmosphere in classroom & 1.09715 & 3.5395 \\
\hline 9 & Encourages good performance & 1.00641 & 3.7697 \\
\hline 10 & Provides different exercises that suits different individuals & 1.07620 & 2.5789 \\
\hline 11 & Encourages students to express their thoughts and ideas & 1.09546 & 3.6776 \\
\hline 12 & Considers the interests of students & 1.16890 & 3.1053 \\
\hline 13 & Considers the needs of slow learners & 1.17099 & 2.5789 \\
\hline 14 & Develops friendly relationships with students & 1.10411 & 3.3026 \\
\hline 15 & Considers the needs of advanced students & 1.11532 & 3.4671 \\
\hline 16 & Gives assignments that suit the level of students & .96361 & 3.1579 \\
\hline 17 & Organizes group discussions to solve class problems & 1.10190 & 3.4342 \\
\hline 18 & Prepares the necessary educational tasks prior to class & 1.10984 & 3.7566 \\
\hline 19 & $\begin{array}{l}\text { Distribute responsibilities among students to do exercises that } \\
\text { are included in the curriculum or extra exercises }\end{array}$ & 1.20935 & 3.3158 \\
\hline 20 & Runs lesson time effectively & .97109 & 3.7763 \\
\hline 21 & Explains ambiguous issues in the lesson & .96521 & 3.7961 \\
\hline 22 & Presents the lesson contents in a systematic flow & 1.17067 & 3.7697 \\
\hline 23 & Uses various educational methods & 1.14706 & 2.9539 \\
\hline 24 & Uses various teaching strategies & 1.04364 & 3.0592 \\
\hline 25 & Provides clear instructions for asked assignments & .96702 & 3.5724 \\
\hline 26 & States the lesson objectives before teaching & 1.08827 & 3.9671 \\
\hline 27 & Uses appropriate speed when explain a lesson & 1.08731 & 3.3487 \\
\hline 28 & Assessing students during the learning process & 1.28373 & 3.3158 \\
\hline
\end{tabular}




\begin{tabular}{llcc}
29 & Uses suitable and clear language while teaching & 1.17803 & 3.6711 \\
30 & $\begin{array}{l}\text { Assures that all students can see provided educational tasks } \\
\text { clearly }\end{array}$ & 1.23389 & 2.9737 \\
31 & Assures that students are properly seated & 1.44059 & 2.8684 \\
32 & Assures good ventilation of the classroom & 1.36950 & 2.3224 \\
33 & Assures that classroom has good lighting & 1.338153 & 2.9276 \\
34 & Avoid sources of noise that hinder the process of learning & 1.41883 & 3.0132 \\
\hline
\end{tabular}

Description of table 2:

\begin{tabular}{|c|c|c|c|c|c|c|}
\hline Domains & $\mathrm{N}$ & & Minimum & Maximum & Mean & Std. Deviation \\
\hline Domain1 & 152 & & 6.00 & 28.00 & 20.4276 & 3.44993 \\
\hline Domain2 & & 152 & 11.00 & 52.00 & 36.4671 & 6.46121 \\
\hline Domain3 & & 152 & 12.00 & 45.00 & 42.3026 & 6.37050 \\
\hline Domain4 & & 152 & 5.00 & 23.00 & 14.1053 & 4.88701 \\
\hline Total & & 152 & 34.00 & 151.00 & 113.3026 & 17.48416 \\
\hline
\end{tabular}

$\mathrm{N}=$ Number of students.

Domain 1: Aspects related to the behavior of students and it had six items.

Domain 2: Aspects concerning classroom atmosphere and the need of students.

Domain 3: Aspects related to planning for a lesson and educational tasks.

Domain 4: Aspects related organizing and preparing classroom environment.

\subsection{Findings of the Study}

The results of the first question: To what degree is effective classroom management components applies by teaching staff of the vocational education department from the perspective of students?

Table (2) shows that all items got all answers as "strongly agree" or "agree" for a mean of 2.5. This means that the scale items got positive evaluation from students.

The results of second question: Does the degree of applying effective classroom management components vary according to the gender of the students?

To provide answers for this question mean and standard deviations for respondents of all scale items were calculated. The differences between averages were tested after that using $\mathrm{T}$ - Table 3 shows the statistics and the results of T-test. 
Table 3: Mean and Standard Deviation of Male and Female of all Domains

\begin{tabular}{cccccc}
\hline Domains & Gender & $\mathrm{N}$ & Mean & $\begin{array}{c}\text { Standard } \\
\text { Deviation }\end{array}$ & $\begin{array}{c}\text { Std. Error } \\
\text { Mean }\end{array}$ \\
\hline \multirow{2}{*}{ Domain 1 } & Male & 58 & 21.3966 & 1.73650 & 0.22801 \\
& Female & 94 & 19.8398 & 4.06569 & 0.41934 \\
Domain 2 & Male & 58 & 36.9483 & 5.28295 & 0.69369 \\
& Female & 94 & 36.1702 & 7.10238 & 0.73255 \\
Domain 3 & Male & 58 & 41.2414 & 4.57035 & 0.60012 \\
& Female & 94 & 42.9574 & 7.20799 & 0.74345 \\
Domain 4 & Male & 58 & 15.3276 & 4.82824 & 0.63398 \\
& Female & 94 & 13.3511 & 4.79405 & 0.49447 \\
Total & Male & 58 & 114.9138 & 12.73245 & 1.67185 \\
& Female & 94 & 112.3085 & 19.85865 & 2.04826 \\
\hline
\end{tabular}

Table (3) above shows that the mean square of female respondents is (112.3085) which is less than the mean of male respondents (114.9138). This difference is not statistically significant at $\alpha=0.05$ if $t$ equals .0892 .

Table 4: T-test of the differences between Male and Female of all Domains

\begin{tabular}{|c|c|c|c|c|c|c|c|c|c|}
\hline \multirow{4}{*}{ Domains } & \multirow{2}{*}{\multicolumn{2}{|c|}{$\begin{array}{l}\text { Equality } \\
\text { Variances }\end{array}$}} & \multirow{2}{*}{\multicolumn{7}{|c|}{ t-test for Equality of Means }} \\
\hline & & & & & & & & & \\
\hline & \multirow[t]{2}{*}{$\mathrm{F}$} & \multirow[t]{2}{*}{ Sig. } & \multirow[t]{2}{*}{$\mathrm{t}$} & \multirow[t]{2}{*}{ df } & \multirow[t]{2}{*}{$\begin{array}{l}\text { Sig. } \\
\text { (2-tailed) }\end{array}$} & \multirow[t]{2}{*}{$\begin{array}{l}\text { Mean } \\
\text { Difference }\end{array}$} & \multirow[t]{2}{*}{$\begin{array}{l}\text { Std. Error } \\
\text { Difference }\end{array}$} & \multicolumn{2}{|c|}{$\begin{array}{l}95 \% \text { Confidence Interva } \\
\text { of the Difference }\end{array}$} \\
\hline & & & & & & & & Lower & Upper \\
\hline \multirow{2}{*}{ Domain 1} & \multirow{2}{*}{21.36} & \multirow{2}{*}{.000} & 2.780 & 150 & .006 & 1.56676 & .56362 & .45310 & 2.68043 \\
\hline & & & 3.282 & 136.634 & .001 & 1.56676 & .47733 & .62286 & 2.51067 \\
\hline \multirow{2}{*}{ Domain 2} & \multirow{2}{*}{.856} & \multirow{2}{*}{.356} & .720 & 150 & .473 & .77806 & 1.08075 & -1.35703 & 2.91316 \\
\hline & & & .771 & 144.714 & .442 & .77806 & 1.00888 & -1.21598 & 2.77210 \\
\hline \multirow{2}{*}{ Domain 3} & \multirow{2}{*}{5.408} & \multirow{2}{*}{.021} & -1.622 & 150 & .107 & -1.71607 & 1.05800 & -3.80657 & .37444 \\
\hline & & & -1.766 & 149.866 & .074 & -1.71607 & .95543 & -3.60393 & .17179 \\
\hline \multirow{2}{*}{ Domain 4} & \multirow{2}{*}{.290} & \multirow{2}{*}{.591} & 2.463 & 150 & .015 & 1.97652 & .80265 & .39075 & 3.56248 \\
\hline & & & 2.458 & 120183 & .015 & 1.97652 & .80401 & .38467 & 3.56838 \\
\hline \multirow{2}{*}{ Total } & \multirow{2}{*}{6.915} & \multirow{2}{*}{.009} & .892 & 150 & .374 & 2.60528 & 2.92135 & -3.16702 & 8.37759 \\
\hline & & & .985 & 149750 & .326 & 2.60528 & 2.64395 & -2.61898 & 7.82955 \\
\hline
\end{tabular}

Domain $1=$ total 1 , Domain $2=\operatorname{total} 2$, Domain $3=$ total $3, \quad$ Domain $4=$ total 4.

The whole questionnaire $=$ total

Table (4) shows that there's statistically differences at $\alpha=0.05$ between male and female in domains 1 and 4. This explains that the relation between the students' assessment levels of teachers performance of classroom management elements doesn't differ according to their gender in general, but it differs regarding to domain 1 which is related to the behavior of 
students and domain 4 which is related to organizing and preparing of the classroom environment.

The results of third question: Does the degree of applying effective classroom management components vary according to the academic year level of students?

Table 5: ANOVA test between students according to the academic year level

\begin{tabular}{|c|c|c|c|c|c|}
\hline Domains & $\begin{array}{l}\text { Sum of } \\
\text { squares }\end{array}$ & Df. & $\begin{array}{l}\text { Mean } \\
\text { square }\end{array}$ & $\mathrm{F}$ & Sig. \\
\hline \multirow{2}{*}{ Total 1 Between Groups } & 67.593 & 3 & & \multirow{3}{*}{1.928} & \multirow{3}{*}{.128} \\
\hline & 1729.611 & 148 & $\begin{array}{l}22.531 \\
11687\end{array}$ & & \\
\hline Within Total & 1797.204 & 151 & & & \\
\hline \multirow{2}{*}{ Total 2 Between Groups } & 69.022 & 3 & 23007 & \multirow{3}{*}{.546} & \multirow{3}{*}{.652} \\
\hline & 6234.813 & 148 & $\begin{array}{l}20.001 \\
12.127\end{array}$ & & \\
\hline Within Total & 6303.836 & 151 & 42.127 & & \\
\hline \multirow{3}{*}{$\begin{array}{c}\text { Total } 3 \text { Between Groups } \\
\text { Within Total }\end{array}$} & 312.984 & 3 & 104.32 & \multirow{3}{*}{2.655} & \multirow{3}{*}{.051} \\
\hline & 5815.095 & 148 & 8 & & \\
\hline & 6128.079 & 151 & 39.291 & & \\
\hline \multirow{3}{*}{$\begin{array}{c}\text { Total } 4 \text { Between Groups } \\
\text { Within Total }\end{array}$} & 119.631 & 3 & 39.877 & \multirow{3}{*}{1.693} & \multirow{3}{*}{.171} \\
\hline & 3486.685 & 148 & 23.559 & & \\
\hline & 3606.316 & 151 & & & \\
\hline Total for all Domains & 1327.121 & 3 & 422.37 & \multirow{3}{*}{1.460} & \multirow{3}{*}{.228} \\
\hline Between Groups & 44832.958 & 148 & 30292 & & \\
\hline Within Total & 46160.079 & 151 & $\begin{array}{c}302.92 \\
5\end{array}$ & & \\
\hline
\end{tabular}

Table 5 shows the absence of any statistically significant differences between students as a result of their academic year level.

\section{Recommendations}

The result of this study show the importance of the assessment of effective classroom management components in causing a significant improvement in the teaching process The researchers recommended that the stakeholders in different educational institutions should consider assessing these components of effective classroom management because assessment has a vital role in forming the necessary basic skills for the students who are our future prospective teachers.

The results of this study showed that students have the potential to evaluate the effective classroom management components. They are also interested in assessing the performance of their teachers. Therefore, the researchers recommend that faculty members give serious consideration to the views of students and encourage them to express their point of view and take their observations in order to improve their performance and avoid the negative aspects. 
In the light of this study, the researchers will submit a proposal to the university administration to establish a center to develop the skills of faculty members in the educational and behavioral aspects.

\section{References}

Abrami, P.C., Apollonia, S., \& Rosenfield, S. (1997). Effective teaching in higherr education. Perry, R.P., Smart, J.C., Eds,; Agathon; New York, 321- 369.

Al-Balq'a Applied University / strategic Plan, 1998.

Emmer, E., Everston C., Sanford and J., \& Clement B. (1989). Classroom Management for Secondary Teachers. Englewood Cliffs, NJ. Prentiic - Hall, 137,66.

Kauchak, D., \& Eggcn, P. (1992). Learning and Teaching: Research Based Methods. Boston: Allyn and Bacon, 486.

Medley, D., M. (1979). The Effectiveness of Teachers. In P.L. Peterson And H.J.Walberg, (Eds.), Research on Teaching: Concepts, Findings, and Implications (McCutchan Piplishing Corp ,11-27.

Saber, Mohieldin. (1982). Role of Higher Education in the Development of cultural Identity. Arab Journal of Education. Arab Organization for Education, Science and Culture, 2(2), 43.

Wang, M., Kargel,G., \& Walberg, H. (1994). What Helps Students Learn? Educational Leadership, 574, 74-79.

Wolfgang, C. (1995). Solving Discipline Problems. MA Needham Hights., Allyn and Bacon, (22).

Yosef and Naefh Qutami, Psychological Basses of Classroom Management. (2002). Dar Alfeker of printing, publishing and distribution, Jordan, 13.

Yosef and Naefh Qutami, Psychological Basses of Classroom Management. (2002). Dar Alfeker of printing, publishing and distribution, Jordan, 19-21.

\section{Copyright Disclaimer}

Copyright reserved by the author(s).

This article is an open-access article distributed under the terms and conditions of the Creative Commons Attribution license (http://creativecommons.org/licenses/by/3.0/). 